\title{
Research
}

\section{RECONSTRUCTING A MID-CRETACEOUS LANDSCAPE FROM PALEOSOLS IN WESTERN CANADA}

\author{
DAVID F. UFNAR, ${ }^{1}$ LUIS A. GONZÁLEZ, ${ }^{2}$ GREG A. LUDVIGSON,${ }^{3 *}$ ROBERT L. BRENNER, ${ }^{4}$ BRIAN J. WITZKE, ${ }^{3}$ AND DALE LECKIE ${ }^{5}$ \\ ${ }^{1}$ University of Southern Mississippi, Hattiesburg, Mississippi 39406, U.S.A. \\ ${ }^{2}$ University of Kansas, Lawrence, Kansas 66045-7613, U.S.A. \\ ${ }^{3}$ Iowa Geological Survey Bureau, Iowa City, Iowa 52242, U.S.A. \\ ${ }^{4}$ Department of Geoscience, University of Iowa, Iowa City, Iowa 52242-1379, U.S.A. \\ ${ }^{5}$ Nexen Inc., Calgary, Alberta T2P 3P7, Canada \\ e-mail:david-ufnar@usm.edu
}

\begin{abstract}
The Albian Stage of the mid-Cretaceous was a time of equable climate conditions with high sea levels and broad shallow epeiric seas that may have had a moderating affect on continental climates. A Late Albian landscape surface that developed during a regression and subsequent sealevel rise in the Western Canada Foreland Basin is reconstructed on the basis of correlation of paleosols penetrated by cores through the Paddy Member of the Peace River Formation. Reconstruction of this landscape refines chronostratigraphic relationships and will benefit future paleoclimatological studies utilizing continental sphaerosiderite proxy records. The paleosols developed in estuarine sandstones and mudstones, and they exhibit evidence of a polygenetic history. Upon initial exposure and pedogenesis, the Paddy Member developed deeply weathered, well-drained cumulative soil profiles. Later stages of pedogenesis were characterized by hydromorphic soil conditions. The stages of soil development interpreted for the Paddy Member correlate with inferred stages of pedogenic development in timeequivalent formations located both basinward and downslope (upper Viking Formation), and landward and upslope (Boulder Creek Formation). On the basis of the genetic similarity among paleosols in these three correlative formations, the paleosols are interpreted as having formed along a single, continuous landscape surface. Results of this study indicate that the catena concept of pedogenesis along sloping landscapes is applicable to ancient successions.
\end{abstract}

Sphaerosiderites in the Paddy Member paleosols are used to provide proxy values for meteoric $\delta^{18} \mathrm{O}$ values at $52^{\circ} \mathrm{N}$ paleolatitude in the Cretaceous Western Interior Basin. The meteoric $\delta^{18} \mathrm{O}$ values are used to refine existing interpretations about the mid-Cretaceous paleolatitudinal gradient in meteoric $\delta^{18} \mathrm{O}$ values, and the mid-Cretaceous hydrologic cycle.

\section{INTRODUCTION}

The purpose of this study is twofold. First, we will show that the paleosols developed in the Paddy Member of the Peace River Formation near the town of Peace River in Western Alberta (Fig. 1) correlate with paleosols developed in the upper Viking Formation farther eastward in the basin and with the Walton Creek Member of the Boulder Creek Formation approximately 100 kilometers to the west. Second, we will show that sphaerosiderites observed in paleosols of the Paddy Member have $\delta^{18} \mathrm{O}$ values that help further constrain a paleolatitudinal gradient of meteoric $\delta^{18} \mathrm{O}$ values in the North American Cretaceous Western Interior Basin (KWIB; Ufnar et al. 2002).

The Paddy and Cadotte members of the Peace River Formation in western Alberta correlate with the Boulder Creek Formation to the west

\footnotetext{
* Present address: Kansas Geological Survey, University of Kansas, 1930 Constant Avenue, Lawrence, Kansas, 66047-3726, U.S.A.
}

and the Viking Formation to the east. These deposits all have similar characteristics that may be attributed to Late Albian sea-level fluctuations (Fig. 2; Leckie 1987). These formations were deposited at approximately $52^{\circ} \mathrm{N}$ paleolatitude in the Rocky Mountain foothills in one of several marine-nonmarine clastic wedges within the Cretaceous Western Interior Basin (Gibson 1992). The chronostratigraphic and paleogeographic relationship between paleosols of the Paddy Member, the Walton Creek Member of the Boulder Creek Formation, and the Upper Viking Formation permit the reconstruction of an ancient landscape and provide an example of how modern analogue soils can be used to assist in unraveling complex pedogenic histories from ancient soil successions. These correlations will be important to future modeling studies that will focus on reconstructing brief intervals of the Late Albian greenhouse warming. Thus far, paleohydrologic modeling from sphaerosiderite proxy records (White et al. 2001; Ufnar et al. 2002) has combined data from the Middle to Late Albian, a time range of approximately $10 \mathrm{My}$. The correlation of sphaerosiderite-bearing units in different locales such as that presented here may lead to paleoclimatological reconstructions for shorter chronostratigraphic intervals (e.g., 2-3 Myr or less).

This study provides an empirical data set from a terrestrial proxy that is used to constrain changes in precipitation isotopic values during the Greenhouse world of the Late Albian. Geochemical and sedimentological techniques are used to evaluate changes in alluvial and estuarine architecture and to correlate regional paleosols and reconstruct an ancient landscape on the orogenic margin of the Western Interior Seaway. These data are valuable to climate modelers because they provide a terrestrial proxy record for precipitation from a high paleolatitude and they provide a means to tie the terrestrial paleoclimate records in the Western Canadian Foreland Basin to the marine realm where chronostratigraphic control is more refined.

\section{Geologic Setting}

The Peace River Formation consists of Lower Cretaceous sandstones and shales of the Fort St. John Group, cropping out near the Smoky and Peace rivers (McConnell 1893; Dawson 1881). The Peace River Formation is subdivided into three members, the basal offshore-marine Harmon Member, the middle shoreface-marine Cadotte Member, and the upper estuarine Paddy Member (Alberta Study Group 1954; Stelck and Leckie 1990a, 1990b). The early Late Albian Paddy Member of the Peace River Formation correlates with the Walton Creek Member of the Boulder Creek Formation in the foothills region and the upper Viking Formation in central Alberta (Fig. 2; Stelck 1958; Stott 1982; Stelck and Leckie 1990a, 1990b; Leckie and Singh 1991).

The Paddy Member was deposited during an episode of overall longterm global sea-level rise that extended from the Albian through the 


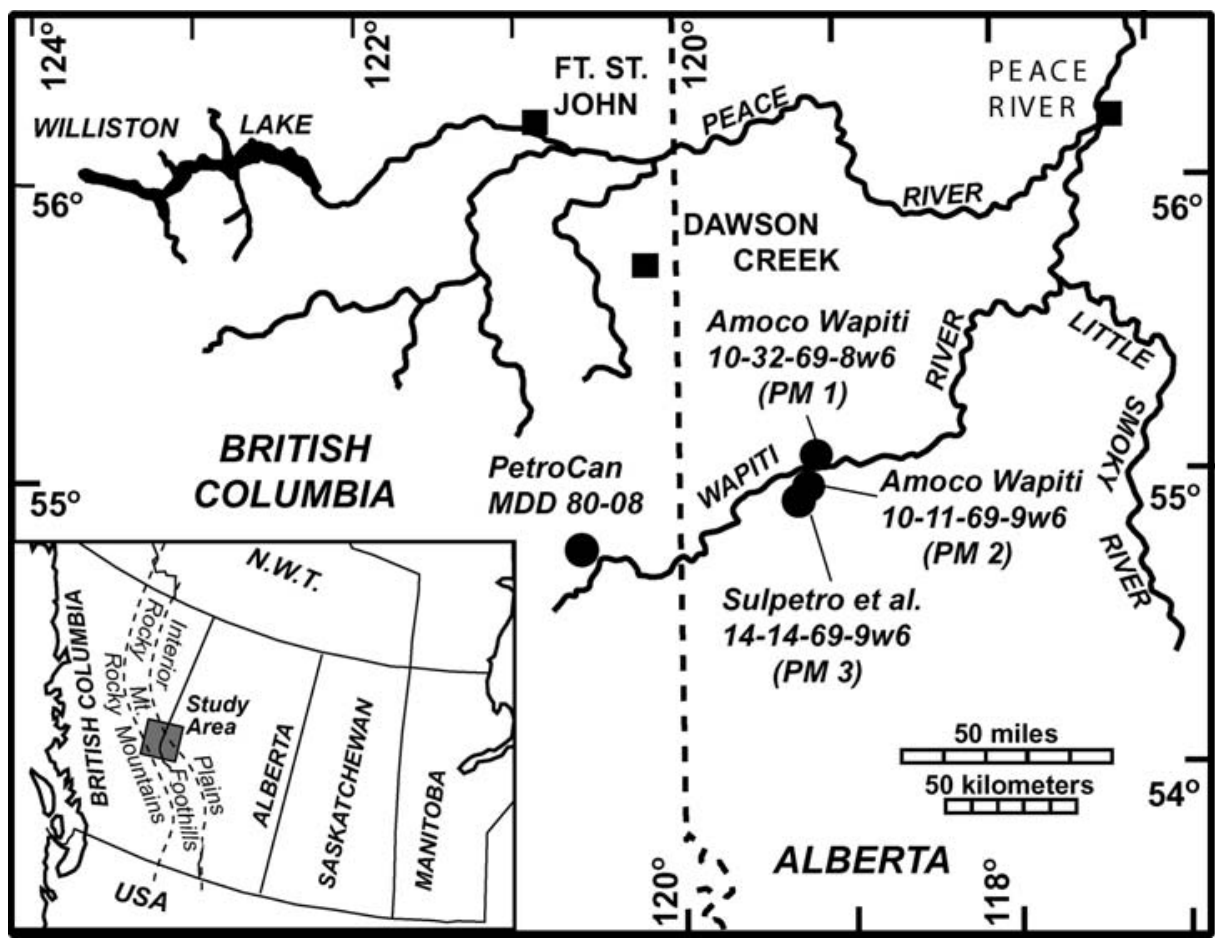

FIG. 1.- Map illustrating the Peace River area and the location of the Paddy Member and Boulder Creek Formation cores analyzed for this study.

Santonian (Haq et al. 1987). The Paddy Member deposits formed during a time of rapid flexural subsidence of the North American craton, the initial phase of the Kiowa-Skull Creek cycle (Kaufmann and Caldwell 1993), global eustatic sea-level rise (Haq et al. 1987), and depositional cycle 3 of Leckie and Smith (1992) in the Western Canada Foreland Basin. The estuarine valley fill of the Paddy Member was deposited on a regional unconformity (sequence boundary) that was incised into the progradational shoreface deposits of the Cadotte Member (Taylor et al. 2002; Leckie and Smith 1992; Stelck and Leckie 1990a). An ooidal ironstone was deposited directly over the unconformity surface and marks the boundary between the Paddy and Cadotte members (Taylor et al. 2002). Sea-level rise during the transgressive phase of the Kiowa-Skull Creek cycle (Kauffman and Caldwell 1993) provided an increase in accommodation space for deposition of the Paddy
Member and ultimately led to total flooding of the area by the Shaftsbury Sea (Leckie and Reinson 1993; Leckie et al. 1990a; Leckie et al. 1990b).

The Paddy Member in the vicinity of the town of Peace River, Alberta, can be subdivided into three units. The basal unit consists of deposits formed in tidally influenced point bars and shoals in the middle to upper reaches of a fluvial estuary. The middle unit is dominated by tidal flat and bay-fill deposits that exhibit extensive pedogenic modification. The upper unit of the Paddy Member consists of subtidal shoal deposits that formed near the entrance of an estuary (Leckie and Singh 1991). The paleosols which occur in the middle unit of the Paddy Member are the focus of this study, and they are correlated with paleosols which occur in the Boulder Creek and Viking Formations in the locations described below.

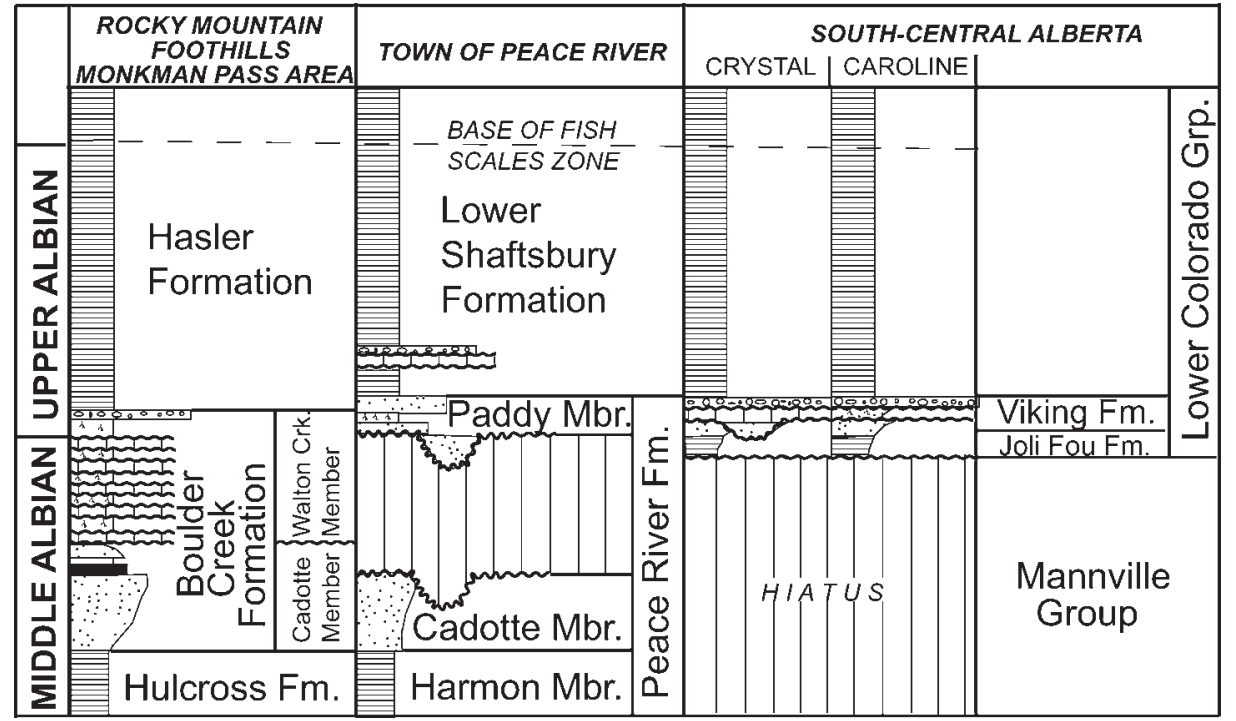

FIG. 2.-Stratigraphic correlation chart illustrating the age relationships established between the Peace River, Boulder Creek, and Viking Formations between the geographic locations examined in the present study (modified from Leckie and Smith 1992 and Gibson 1992). 
The Walton Creek Member of the Boulder Creek Formation described in the MDD 80-08 core generally consists of approximately 90 meters of nonmarine, alluvial-plain sandstones and mudstones which contain 15 closely spaced cumulative sphaerosiderite-bearing paleosols (Stott 1982; Leckie et al. 1989; Gibson 1992; Ufnar et al. 2001). The nonmarine strata of the Walton Creek Member correlates with the Paddy Member of the Peace River Formation in the Alberta Plains near the town of Peace River (Leckie et al. 1990b; Gibson 1992; Leckie and Smith 1992).

The Late Albian Viking Formation in the Caroline Field of southcentral Alberta (Davies and Walker 1993) generally consists of tidally reworked transgressive conglomerates unconformably overlying progradational shoreface-nearshore sandstones (Leckie 1987). A mottled maroon and gray-green mudstone paleosol is recognized in the upwardcoarsening, progradational offshore-shoreface deposits near the top of the Viking Formation in well 7-4-33-6 at 2733.8 m depth (Davies and Walker 1993). The Paddy Member of the Peace River Formation is a northern correlative of the Viking Formation of the Rocky Mountain Foothills of west central Alberta and the central Alberta Plains (Leckie et al 2000; Leckie and Reinson 1993; Leckie et al. 1990b).

\section{Core Description Methods}

Samples were collected from three cores through the Paddy Member of the Peace River Formation from the following wells: (1) The Amoco (and others) Wapiti well 10-32-69-8w6 (lat. 55.020593 long. 119.177604 ${ }^{\circ}$ ); this core will be referred to as PM 1; (2) The Amoco (and others) Wapiti well 10-11-69-9w6 (lat. 54.961994 long. 119.254323); this core will be referred to as PM 2; and (3) the Sulpetro (and others) Elm well 14-1469-9w6 (lat. $54.9777949^{\circ}$ long. $119.263533^{\circ}$ ); this core will be referred to as PM 3. The paleosols were described following the methods of the Soil Survey Staff (1999), and 37 samples were collected for micromorphological analyses following the methods of Bullock et al. (1985). The detailed micromorphological descriptions can be found in Appendix 1, which is held in the JSR Data Repository (see Acknowledgments section). The samples are labeled according to the depth to the top of the extracted specimen or core "plug." Point counts of $\mathrm{N}=300$ were performed to determine the paleosol textures. Core descriptions of the MD 80-08 core through the Boulder Creek Formation and isotopic analyses of the sphaerosiderite-bearing horizons are in Leckie et al. (1989) and Ufnar et al. (2001). Paleosol data from the Viking Formation in the Caroline Field area of Alberta was obtained from R.G. Walker (personal communication) and Davies and Walker (1993).

In this paper we describe the morphological characteristics of the Paddy Member paleosols and discuss the implications of these characteristics for changes in alluvial architecture and relative sea level. The Paddy Member paleosols are then correlated with contemporaneous deposits to reconstruct an ancient landscape surface. Finally, the stableisotope values and geochemistry of sphaerosiderites in the Paddy Member paleosols are described, and discussed regarding their importance to paleoclimatological investigations of the Cretaceous Western Interior Basin.

\section{PADDY MEMBER PALEOSOLS}

\section{Paleosol Morphology}

The pedogenically modified deposits of the Paddy Member are cumulative paleosols that range from 2.5 to 5 meters in thickness (Fig. 3). The rock textures generally range from very fine-grained sandstones to mudstones and silty claystones. The mudstones typically display a blocky fracture pattern, and prominent clay coatings and pedogenic slickensides were often observed on the faces of the broken blocky units of the core. These blocky units may be representative of "peds," however, compaction and lithification probably altered the pedogenic structures. The paleosols are characterized by gleyed colors with low to moderate values and very low chromas ranging from greenish gray to dark greenish-gray and greenish-black colors. The values and chromas were lowest (blackest) near the tops of the paleosols, and the highest values were noted near the bases of the paleosols. Carbonaceous material is abundant throughout the pedogenically altered deposits and the highest concentrations typically occur in the uppermost paleosol horizons. Some very well preserved plant fossils are contained within the mudstones. Fine, branching, and bifurcating carbonaceous root traces are observed. Sphaerosiderites are observed as dense patches or in smaller clusters of individuals in thin stratigraphic intervals generally $<10 \mathrm{~cm}$ thick. The overlying and underlying stratigraphic units generally exhibit a dominance of primary physical sedimentary structures, and a lack of pedogenic features.

It appears that there is nearly complete preservation of the soil profiles, with minor truncation of the uppermost horizons. It is not possible to determine how much of the profile is missing; however, there is extensive preservation of organic rich horizons that may be remnant A horizons. The uppermost horizons do, however, typically exhibit evidence of illuvial silicate clays, which is a characteristic of B horizons (Birkeland 1999). Therefore the upper portions of the paleosols are referred to as transitional $\mathrm{AB}$ horizons, and they may reflect the cumulative nature of these paleosols. The assigned master and subordinate horizon designations of the PM (Paddy Member) paleosols generally exhibit AB, Btg, $\mathrm{Btcg}$, and $\mathrm{Cg}$ horizonation. The $\mathrm{AB}$ horizons are mineral horizons that contain an abundance of organic matter, and some illuvial clay accumulations. The Btg horizons are weathered units that exhibit few if any original depositional features and are characterized by illuvial accumulations of silicate clay $(\mathrm{t})$. The $(\mathrm{g})$ designation indicates that the horizon is predominantly gleyed, or characterized by bluish hues, very low chromas, and a lack of red mottling. The (c) represents concretions or nodules, and in this case the horizons with a "c" subordinate designation are the sphaerosiderite-bearing units. The Cg horizons are the lowermost weathered units where the only prominent pedogenic feature is gleying.

The pedogenically modified deposits all overlie very fine-grained to fine-grained carbonaceous sandstones that exhibit horizontal laminations, small-scale ripple cross-stratification, and wavy-, lenticular-, and flaser-bedded sandstones. Typically, the finer-grained material in the wavy and flaser-bedded units is dominated by finely comminuted carbonaceous debris.

\section{Paleosol Micromorphology}

The observed paleosols of the Paddy Member generally exhibit speckled and striated birefringent fabrics where the silty or sandy clay matrix contains numerous small patches of optically oriented clays or elongated domains of oriented clays or argillans respectively (sepic plasmic fabrics of Brewer 1964). Some of the more clay-rich units are characterized by strial matrix fabrics where large domains of clay in the matrix are in weak optical continuity. Texturally, the upper portions of the paleosols are predominantly clays and silty clays, and the lower portions are silt loams and silty clay loams. Compound, dense, complete clay and silty clay infillings and typic clay coatings (argillans of Brewer 1964) with faint iron oxide hypocoatings (neo-cutans of Brewer 1964), and faint to prominent organic hypocoatings are common in all three paleosols (Fig. 4A, B). Commonly, the clay coatings are fragmented, deformed, and degraded and often exhibit domains that have very diffuse boundaries with the surrounding matrix (Fig. 4C). In some cases the typic clay coatings exhibit very abrupt boundaries with the matrix, and exhibit sharp, sweeping extinction patterns under cross-polarized light. Many domains of oriented clays exhibit wavy, diffuse and grainy extinction patterns, and the boundaries between the matrix and the coatings are gradational. Many of the small patches of oriented clays appear to be 


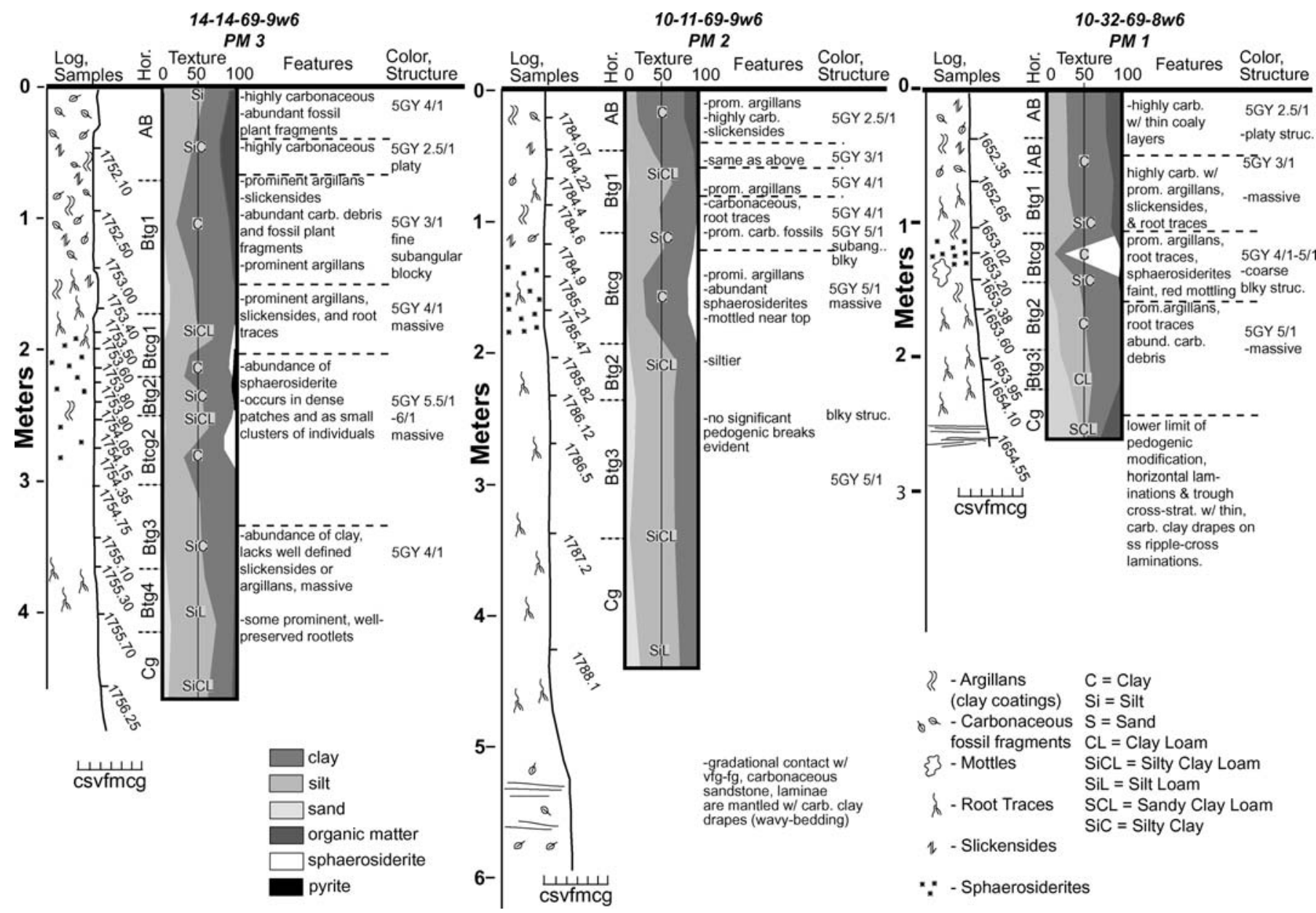

FIG. 3.-Lithologic and pedologic descriptions illustrated for each of the Paddy Member cores analyzed. The lithologic log illustrates the general morphologic features observed in the cores, and a brief description of the prominent features is provided. The diagonal numbers adjacent to the core log indicate the depths from which "core plugs" were obtained for thin sections. The texture graphics illustrate the percentage of sand, silt, clay, organic matter, and siderite quantified from the thin-section point counts. On the basis of the relative percentages of sand, silt, and clay, the horizons have been labeled with the corresponding pedogenic textures (e.g., SiCL silty clay loam). The Munsell colors, horizon designations, and morphological structures are also noted.

fragments of once continuous coatings that were fragmented and assimilated into the matrix. Clay and silty clay infillings are also commonly deformed, and the laminae are sometimes splayed and smeared along the margins of the infilling.

Very small, generally 10-50 $\mu \mathrm{m}$ diameter pyrite framboids are observed throughout the paleosols, but they seldom exceed more than $1 \%$ of the bulk composition of the sediment. The pyrite is observed as small clusters of framboids disbursed throughout the matrix, as inclusions within sphaerosiderite nodules, or as framboids closely associated with carbonaceous fossil materials (Fig. 4D). In some cases, numerous very small framboids $(<20 \mu \mathrm{m})$ are observed as pseudomorphs after organic debris.

Organic debris is common, and occurs in the highest concentrations in the upper few samples from each paleosol. Commonly, the organic debris is finely comminuted carbonaceous fragments that are opaque, and sometimes occur as dendritic filaments. Some of the organic material is very dark brown to rust colored, and has a resinous or vitreous appearance. Some organic material occurs as coatings that weakly to moderately impregnate the matrix. Many of the larger organic fragments exhibit excellent preservation of cellular structures (Fig. 4E, F).

The sphaerosiderites generally range from 0.25 to $0.75 \mathrm{~mm}$ in diameter, and were observed in several distinct horizons within the three paleosols.
The sphaerosiderites are all observed within horizons that are clays (claystones) in the middle portions of the paleosol profile. Typically, the sphaerosiderites at the micro-scale occur as individuals, as small clusters, or in linear arrays (Fig. 5A). In the case of the PM 1, $1653.2 \mathrm{~m}$ sample, however, the sphaerosiderites occur as a densely packed cluster of nodules that displaced most of the surrounding matrix (Fig. 5B). Generally, the sphaerosiderites are characterized by a central core that has a micrite-like, microcrystalline texture. The outer rims of the nodules are generally characterized by radial concentric crystalline microstructures that exhibit the characteristic pseudo-uniaxial cross extinction patterns under crosspolarized light (Fig. 5C). Commonly, 10-15 $\mu \mathrm{m}$ pyrite framboids are observed as inclusions within the sphaerosiderite nodules. It is noteworthy that with few exceptions the pyrite framboids are found only within or rimming the micrite-textured core of the sphaerosiderites (Fig. 5D). The radial-concentric crystalline outer margins of the nodules are generally devoid of pyrite inclusions.

\section{Implications of the Paleosol Morphology}

The morphology and micromorphology of the Paddy Member paleosols is consistent with mid-Cretaceous sphaerosiderite-bearing paleosols elsewhere in the KWIB (e.g. McCarthy and Plint 1998; Ufnar et al. 2001). These paleosols exhibit evidence of significant changes in 

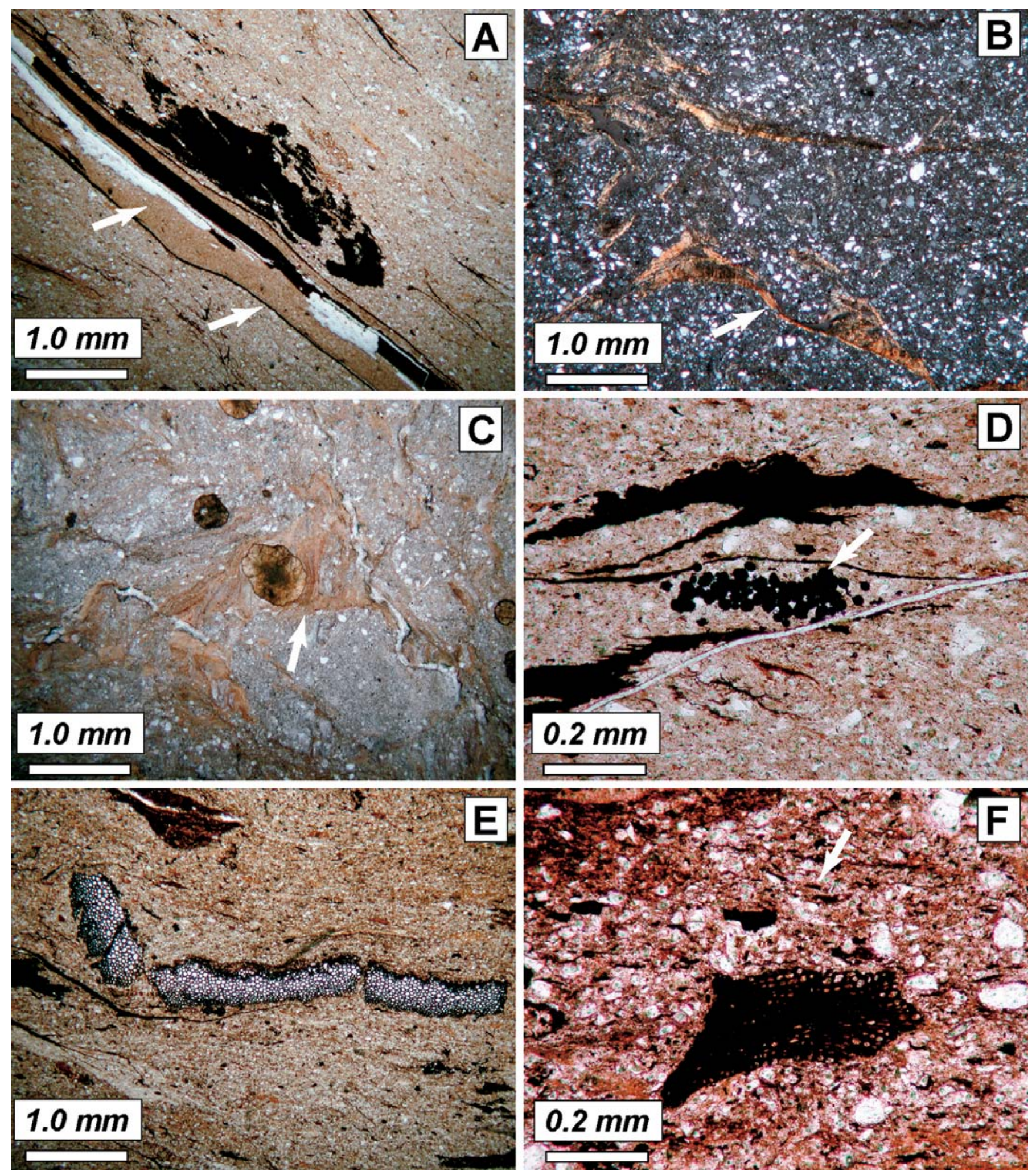

FIG. 4.- Photomicrographs illustrating some of the prominent pedogenic features observed at micro-scale in the PM paleosols. A) The plane-polarized-light image from PM $1(15652.65 \mathrm{~m})$ shows a compound coating of opaque organic material and silicate clays which runs diagonally through the photomicrograph from the top left to the bottom right. The upper arrow points to the well oriented, thick clay coating and the lower arrow points to the thinner, organic coating that is in sharp contact with the surrounding matrix. B) The orange areas are degraded clay coatings in cross-polarized light from the 1786.12 interval of PM 2. C) The arrow indicates a portion of some degraded and deformed clay coatings and infillings which are overprinted by sphaerosiderites (PM 3, $1753.5 \mathrm{~m}$ ). D) The arrow points to a cluster of pyrite framboids observed in close association with carbonaceous organic debris in PM 1 (1652.65 m). E) A fractured piece of carbonaceous material in the center of the photo 

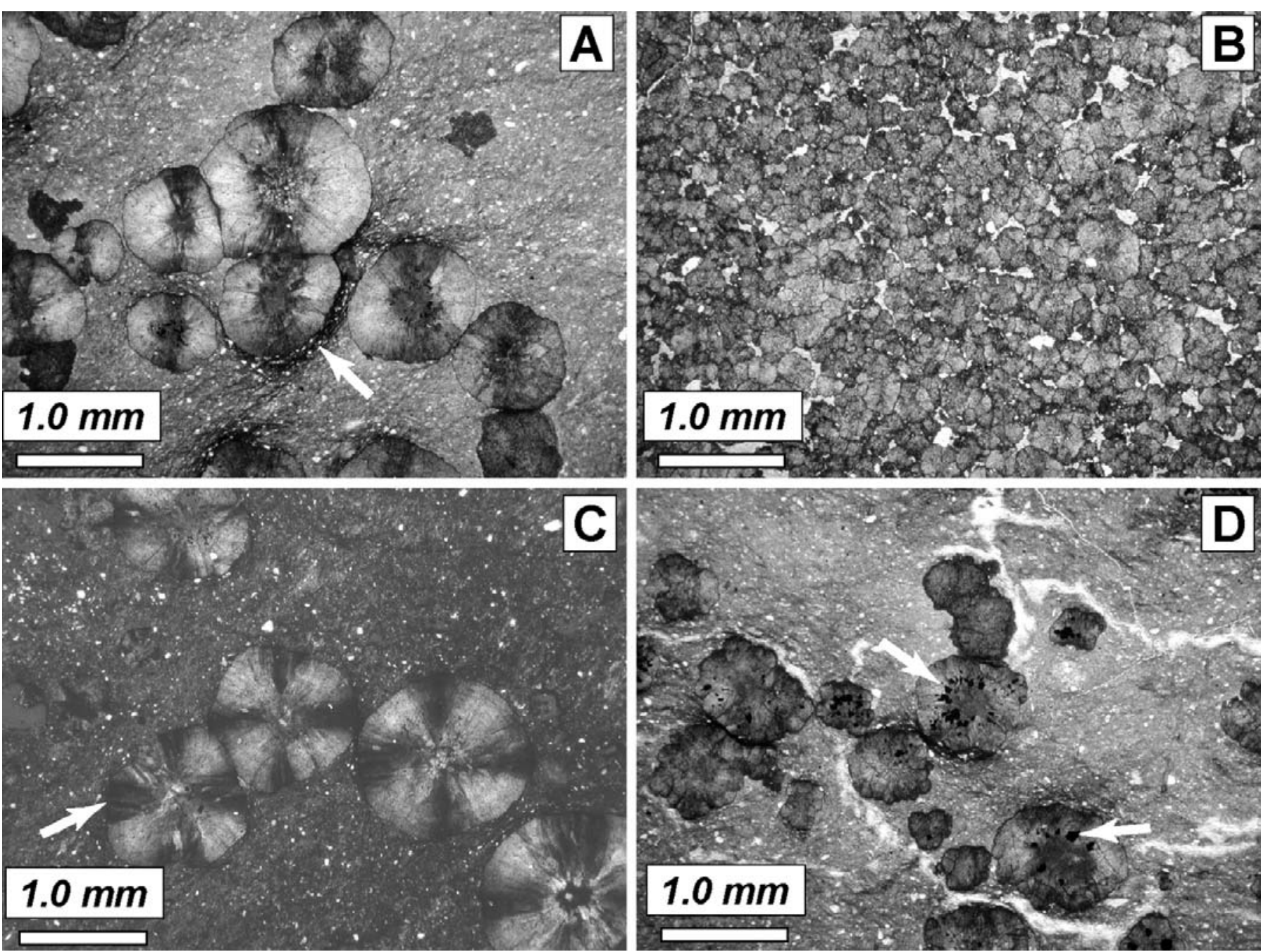

FIG. 5.-Photomicrographs illustrating pedogenic features. A) Sphaerosiderites of PM $3(1754.35 \mathrm{~m})$ are large and well developed. The arrow indicates an area of the clay-dominated matrix that is weakly impregnated with organic matter and is deformed around the siderite nodule. B) The sphaerosiderite-bearing paleosol horizon of PM $1(1653.2 \mathrm{~m})$ is characterized by densely-packed siderite nodules that stand out in high relief compared to the kaolinitic background matrix. C) Examples of the sphaerosiderites of PM $3(1754.35 \mathrm{~m})$ viewed under cross-polarized light and exhibiting the characteristic pseudo-uniaxial cross extinction pattern (arrow). D) The sphaerosiderites of PM $2(1785.21 \mathrm{~m})$ are very well developed, and commonly exhibit pyrite inclusions that surround the microcrystalline textured inner core of the nodules (arrow).

drainage conditions during a polygenetic pedogenic history. The thickness and textural variations through the paleosols suggest that the profiles were cumulative, and pedogenesis continued through periodic depositional events (Kraus 1999). The abundance of clay coatings and infillings is evidence for illuviation of fine-grained sediments through the soil profile, and illuviation occurred when the soils were well drained (FitzPatrick 1984; McCarthy and Plint 1998; McCarthy et al. 1998). The thickness and abundance of clay coatings indicate that the soil was well drained for a long period of time (McCarthy et al. 1999b). The deformation and reworking of clay coatings into the matrix suggests prolonged landscape stability. It is interpreted that most of the clay observed in the paleosols resulted from translocation processes, and very little was inherited from the parent material, which is predominantly very fine-grained, carbonaceous sandstones. The prevalent birefringent fabrics and assimilation of the clay coatings into the matrix may have resulted from shrink-swell reorganization of the soil materials during wettingdrying cycles (FitzPatrick 1984; McCarthy et al. 1998, 1999a; McCarthy and Plint 1998). The compound clay coatings with ferruginous hypocoatings may also reflect cyclic wetting and drying, and some fluctuations in redoximorphic conditions (McCarthy et al. 1998). This well-drained phase of paleosol development represents the early phases of pedogenesis in the Paddy Member.

The drainage conditions appear to have degraded, and the latter stages of pedogenesis were dominated by hydromorphic soil conditions. The prominent gleying, abundance of sphaerosiderite, and well preserved organic debris is indicative of poorly drained, saturated, reducing

$\leftarrow$

exhibits very well-preserved cellular structures, and it is contained within a clay-dominated strial matrix fabric of the $1752.1 \mathrm{~m}$ interval of PM 3 . F) Close-up view of a carbonaceous organic fragment with well-preserved cellular structure. The arrow indicates a particle of finely comminuted carbonaceous debris in the AB horizon of PM $2(1784.22 \mathrm{~m})$ 
conditions in the soils (McCarthy and Plint 1999). These paleosols developed in estuarine deposits that were exposed for a prolonged period of time and then subsequently drowned (Leckie and Reinson 1993). The hydromorphic phase of pedogenesis probably began with base-level rise followed by passive drowning during the early stages of the Kiowa-Skull Creek transgression (Kauffman and Caldwell 1993). Following the paleosol classification scheme of Mack et al. (1993), the PM paleosols are cumulative argillisols that progressed to gleysols during the latter stages of pedogenesis.

\section{Stratigraphic Framework and Paleo-Landscape Development}

Numerous investigators have analyzed the depositional history of Late Albian rocks of the Western Canadian Foreland Basin (e.g., Pattison and Walker 1992, 1994; Leckie and Reinson 1993; Walker and Wiseman 1995; Leckie et al. 1989; Leckie and Singh 1991; MacEachern et al. 1999; Taylor et al. 2002). However, fewer attempts have been made to reconstruct the landscape conditions from Late Albian paleosols in western Canada (Leckie and Reinson 1993). A stratigraphic model with interpreted correlations is presented here to show how changes in relative sea level affected the Late Albian stratigraphic architecture of the Peace River area, and to show how these sea-level changes affected weathering and soil development on the exposed coastal plain. The stratigraphic model is presented to help explain how the paleosols of the Paddy Member of the Peace River Formation might fit into the more regional sequence stratigraphic framework, and correlates with paleosols at a broader scale (e.g., White et al. 2005) to warrant future higher-resolution paleoclimatological reconstructions.

The Paddy Member of the Peace River Formation correlates with the Viking Formation of the Central Alberta Plains (Bloch et al. 1993; Leckie and Smith 1992). The Viking Formation generally consists of siliciclastic sediments that were deposited in a progradational set of cyclic upwardcoarsening shelf to lower-shoreface siltstones and sandstones (Pattison and Walker 1998; MacEachern et al. 1999). A pedogenically modified exposure surface has been described in the Viking Formation south of the Caroline oil field of Alberta (Davies and Walker 1993). The lithostratigraphic and chronostratigraphic correlations strongly suggest that the Viking paleosol described near Caroline correlates with the Paddy Member paleosols near the town of Peace River (Fig. 6). The Viking Formation paleosol is developed at the top of an upward-coarsening shelf to shoreface succession that was deposited over an unconformity surface, labeled the VE3 surface in the central plains of Alberta (Davies and Walker 1993). The VE3 surface correlates with the unconformity between the Paddy and the Cadotte members of the Peace River Formation near the town of Peace River. The VE3 surface also correlates with the sequence boundary denoted by Leckie et al. (1989) in the Boulder Creek Formation MD 80-08 core (Fig. 6).

Transgression of the VE3 surface resulted in shallow-marine shelf deposition of the Viking Formation to the east (basinward), estuarine deposition of the Paddy Member (coast), and alluvial deposition of the Boulder Creek Formation to the west (landward). During a subsequent fall in relative sea level, portions of the Viking Formation were exposed in the seaward direction, and fluvial incision and soil development occurred on the exposed landscape near the town of Peace River and $100 \mathrm{~km}$ farther west in the Monkman Pass (Boulder Creek Formation) area (MDD 80-08 core location Fig. 1). The differences in pedogenic development at each location (described below) are related to differences in position along an ancient sloping exposure surface, and represent a paleo-catena relationship. The coarse-dashed line illustrated in Figure 6 delineates the ancient landscape relationship on the coastal plain between soils that were developing in the PM 1-3 areas, exposed marine deposits of the Viking Formation farther eastward in the basin, and the Boulder Creek Formation alluvial deposits approximately $100 \mathrm{~km}$ to the west of the PM cores. The correlated landscape surface (coarse dashed line in Fig. 6) represents the landscape during the maximum drop in sea-level and maximum exposure of the coastal plain prior to the initial transgression of the Kiowa-Skull Creek sea-level cycle (Kauffman and Caldwell 1993).

Subaerial exposure and pedogenic modification of the Viking Formation correlates with a relative sea-level fall following deposition of the marine deposits upon the VE3 surface (Davies and Walker 1993). To the west and upslope on the coastal plain, the correlative soils forming in the PM area were likely very well drained on the interfluves, and fluvial incision was occurring in the valleys during this stage in landscape development. Farther west and upslope, in the Monkman Pass area, fluvial incision likely dominated during this exposure period. Sea level, and consequently base level began to rise in the basin during the early transgressive phase of the Kiowa-Skull Creek cycle. The well-drained paleosols previously developed in the Viking Formation may have become progressively waterlogged, and began a poorly drained (hydromorphic) phase of pedogenesis (Fig. 7A). Landward, the soils developing on interfluves in the PM area may not have been affected much initially, but with base level rising, incision by fluvial channels may have ceased, and the fluvial depositional systems may have begun to aggrade and fill in the valleys. During this stage of pedogenesis the soils were cumulative, and pedogenic development progressed with the aggrading floodplains. With progressive relative sea-level rise, the soils that developed in the basin were eventually flooded, and the soils developing in the PM1-3 areas eventually became wetland paleosols, and began a poorly drained phase of pedogenic development (Fig. 7B). To the west, in the Boulder Creek Formation, the interfluve soils were likely still well drained, but the incised valleys were gradually filling, and the drainage conditions were degrading (Ufnar et al. 2001). With continued transgression, fully marine conditions existed to the east in the basin, the paleosols developed in the Paddy Member were passively drowned and estuarine conditions ensued, while the soils in the upper Boulder Creek Formation to the west eventually became wetland soils (Fig. 7C). Finally, with continued transgression, the PM area was fully marine, while farther west low-lying wetland paleosols continued to develop (Fig. 7D). Eventually, the westernmost positions were transgressed and covered with the marine Shaftsbury Formation.

The timing of soil phase development in the PM area compared to more basinward paleosols would not have been synchronous because of the difference in landscape position. While the soils developed near the Caroline Field area were being drowned, the soils landward in the PM area would have still been well drained. Maximum soil development occurred in the westernmost positions in what is now the Walton Creek Member of the Boulder Creek Formation. Making correlations here is most difficult, because the entire assemblage is characterized by alluvial deposits with amalgamated and welded, cumulative paleosols developed in aggrading floodplain sediments.

The alluvial architecture and amalgamated paleosols in the Walton Creek Member most likely developed in response to the step-like progradational and retrogradational lithofacies assemblage that characterizes the Viking Formation farther eastward in the basin (Pattison and Walker 1998; Davies and Walker 1993). Episodes of fluvial downcutting and development of well-drained soils on interfluves in the Boulder Creek Formation may correlate with parasequence-scale phases of progradation in the basin. Development of wetland soils in the Boulder Creek Formation may correlate with minor marine flooding surfaces and transgression in the basin (Ufnar et al. 2001).

The pattern of paleosol development in the Boulder Creek Formation is contrary to many studies where the lower parts of paleosol sequences are drab in color and characterized by siderite and pyrite (Cecil et al. 1985; Cecil 1990; Bown and Kraus 1993). Furthermore, the amalgamated Boulder Creek alluvial paleosols do not follow a general trend of aging, draining, and drying upwards (Retallack 1998). The Walton Creek 


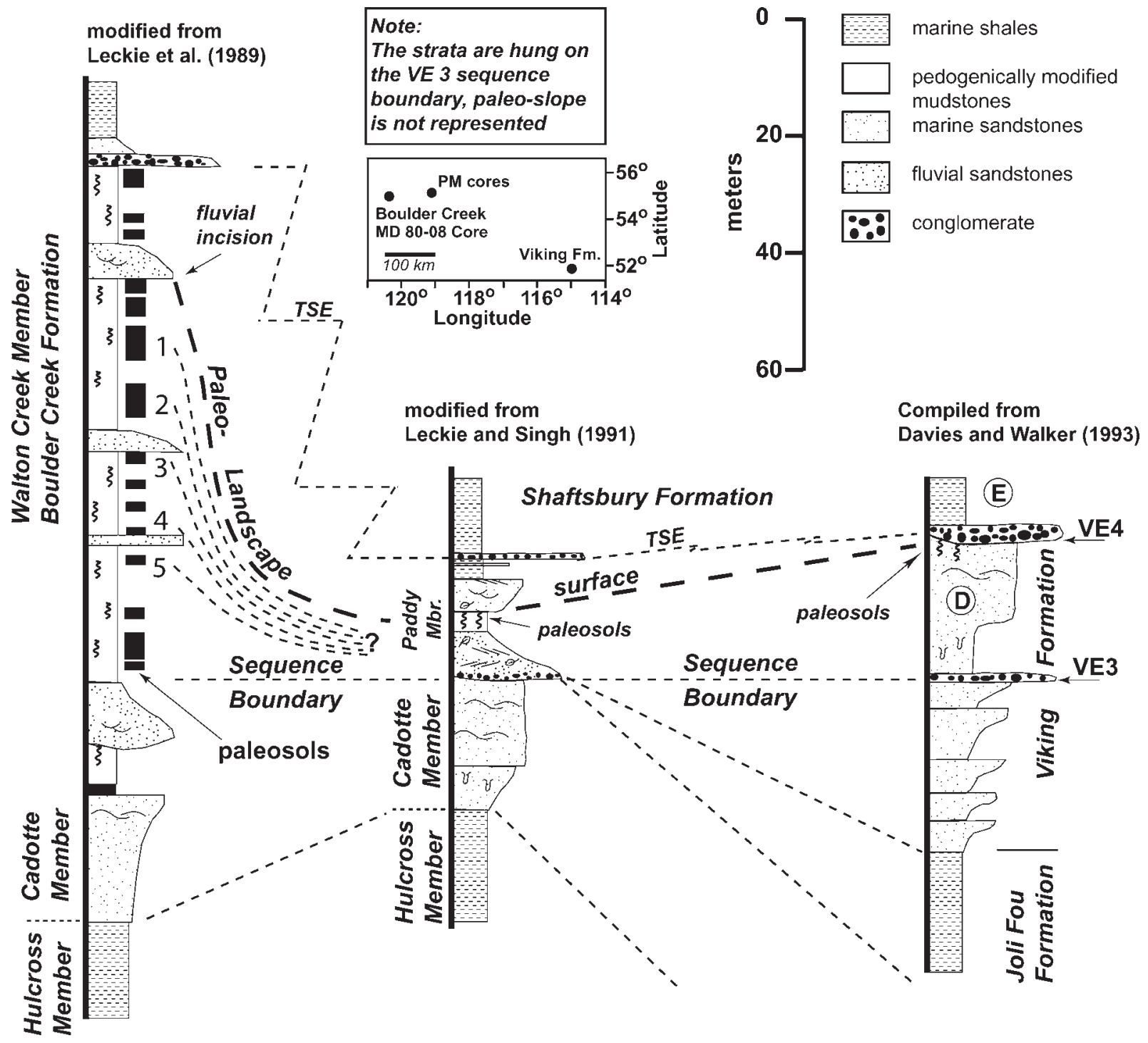

Fig. 6.-A paleo-landscape has been reconstructed from the morphological characteristics and paleogeographic positions of paleosols observed in the Walton Creek Member of the Boulder Creek Formation, the Paddy Member of the Peace River Formation, and the Viking Formation near the Caroline Oil Field in western Alberta. The paleosols in the Paddy Member and the Viking Formation developed during a regressive phase of sea-level during the overall transgression of depositional cycle 3 in the Western Canadian Foreland Basin (Leckie and Smith 1992). The coarse dashed line depicts an ancient, sloping landscape relationship that likely developed during the peak of the regressive phase. While soils which developed in the most basinward positions were poorly drained wetlands that were progressively drowning, the soils that developed in the Paddy Member upslope were well drained on the interfluves. Further west and upslope, in the Boulder Creek Formation, the soils on the interfluves were very well-drained, and the fluvial channels were incising.

Member alluvial section is analogous to Retallack's (1998) sequence stratigraphic model of weakly developed, carbonaceous, non-calcareous, drab hue paleosols (cumulative) formed in a transgressive systems tract.

Thick conglomeratic sandstones occur between 53 and 58.5 meters depth (Fig. 8) in the MDD 80-08 core (coarse dashed line; Fig. 6). The scoured surface that marks the basal contact of the conglomerate may have been incised during the regressive pulse that exposed the marine Viking Formation in the Caroline Field area, and the estuarine Paddy Member near the town of Peace River (Fig. 6). Backfilling of the incised valleys and accumulation of the conglomeratic sandstones in the Boulder Creek Formation may have occurred in response to rising base level associated with rising relative sea level (transgression of the Kiowa-Skull Creek cycle). The accumulation of the conglomeratic sandstones between 53 and 58.5 meters depth in the Boulder Creek Formation observed in the MD 80-08 core is correlated with the poorly drained phase of pedogenic development downslope, and to the east in the PM area. The development of the wetland, sphaerosiderite-bearing paleosols in the Walton Creek Member deposits observed between 38 and 53 meters overlying the conglomeratic sandstones correlates with the bay-fill and estuarine deposits which accumulated in the upper Paddy Member.

\section{ISOTOPIC ANALYSES}

\section{Stable-Isotope Methods}

The sphaerosiderite-bearing intervals were evaluated using transmitted-light, cathodoluminescence, and epifluorescence microscopy. Polished slabs of sphaerosiderite-bearing horizons were microsampled using a microscope-mounted drill assembly with a $0.5 \mathrm{~mm}$ drill bit. Powdered siderite samples extracted for mass spectrometry were 

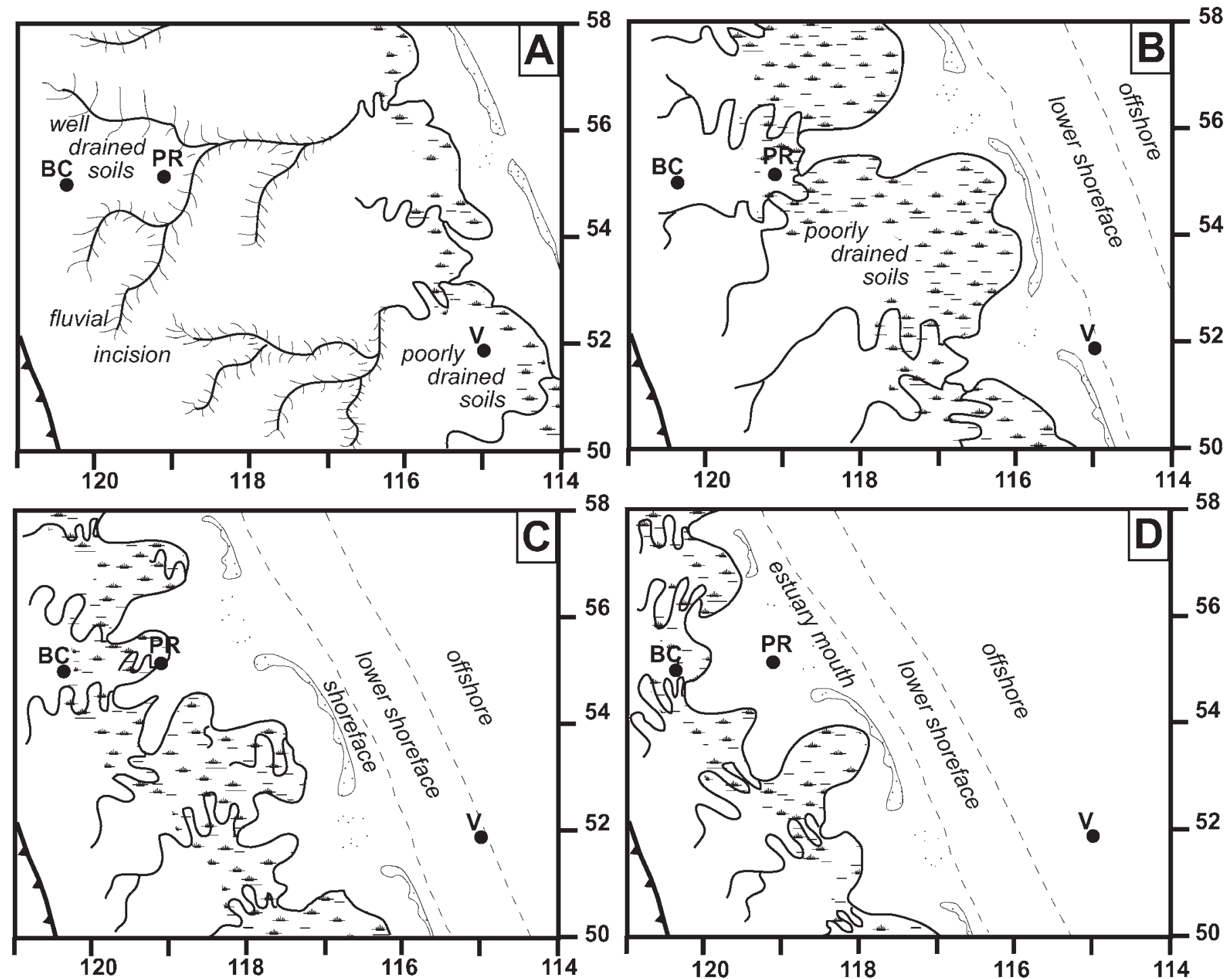

FIG. 7.- The cartoons illustrate a generalized sequence of events that occurred during sea-level rise and transgression over the ancient landscape correlated in Figure 10. The reconstruction is based upon the present geographic location of the cores compared in this study (latitude-longitude on the axis of the diagrams). On the basis of paleogeographic reconstructions the shoreline would be rotated counterclockwise and would have a more northwest-southeast orientation (Leckie and Smith 1992; Scotese 1991). Block A represents the period of maximum regression, exposure, and weathering of the paleo-landscape. The most basinward positions $(\mathrm{V}=\mathrm{Viking}$ paleosol near the Caroline Oil Field) were characterized by low-lying wetland soils; upslope and to the west, the interfluves were characterized by deeply weathered, welldrained soil profiles and the fluvial channels were incising in the Paddy Member and Boulder Creek Formation (PM and BC). Block B depicts the early phases of transgression. The basinward positions are transgressed and become fully marine, while upslope the PM paleosols became waterlogged and hydromorphic and the $\mathrm{BC}$ fluvial systems began to aggrade and the drainage conditions degraded. Block $\mathrm{C}$ illustrates how continued transgression produced estuarine conditions in the PM while upslope the BC fluvial systems continued to aggrade, and the soils were becoming poorly drained. Block D depicts continued transgression, open estuary-mouth conditions in the PR area and poorly drained, hydromorphic soil development in the $\mathrm{BC}$ area.

analyzed at the University of Iowa Paul H. Nelson Stable Isotope Laboratory.

Powdered samples were vacuum-roasted at $380^{\circ} \mathrm{C}$ then reacted with anhydrous phosphoric acid at $72^{\circ} \mathrm{C}$ in an on-line automated Kiel III carbonate reaction device coupled to the inlet of a Finnegan MAT 252 isotope-ratio mass spectrometer. All isotopic values were reported relative to the PeeDee Belemnite (PDB) standard, with analytical precision of better than $\pm 0.05 \%$ for carbon and oxygen. Siderite data were corrected with the experimentally determined temperature-dependent isotope fractionation factor of Carothers et al. (1988).

Electron microprobe analyses were conducted on sphaerosiderites from the $1754.35 \mathrm{~m}$ depth interval of the PM 3 core using a JEOL JXA-8900R electron microprobe at the University of Minnesota. Siderite analyses were performed using wavelength-dispersive spectrometry at an accelerating voltage of $15 \mathrm{kV}$, a beam current of $10 \mathrm{nA}$, and with a beam diameter of $5 \mu \mathrm{m}$. The following X-ray lines and standards were used: $\mathrm{Ca}_{\mathrm{K} \alpha 1}$ (Calcite), $\mathrm{Mg}_{\mathrm{K} \alpha 1}$ (dolomite), $\mathrm{Mn}_{\mathrm{K} \alpha 1}$ (rhodonite), $\mathrm{Fe}_{\mathrm{K} \alpha 1}$ (siderite), and $\mathrm{Sr}_{\mathrm{K} \alpha 1}$ (strontianite).

\section{Stable Isotopes of Oxygen and Carbon and Minor Elements}

Meteoric-Water Compositions.- - The average sphaerosiderite $\delta^{18} \mathrm{O}$ and $\delta^{13} \mathrm{C}$ values for each paleosol horizon are summarized in Table 1 and Figure 9. The meteoric sphaerosiderite lines (MSLs; Ludvigson et al. 
MD 80-08 Core, Boulder Creek Formation

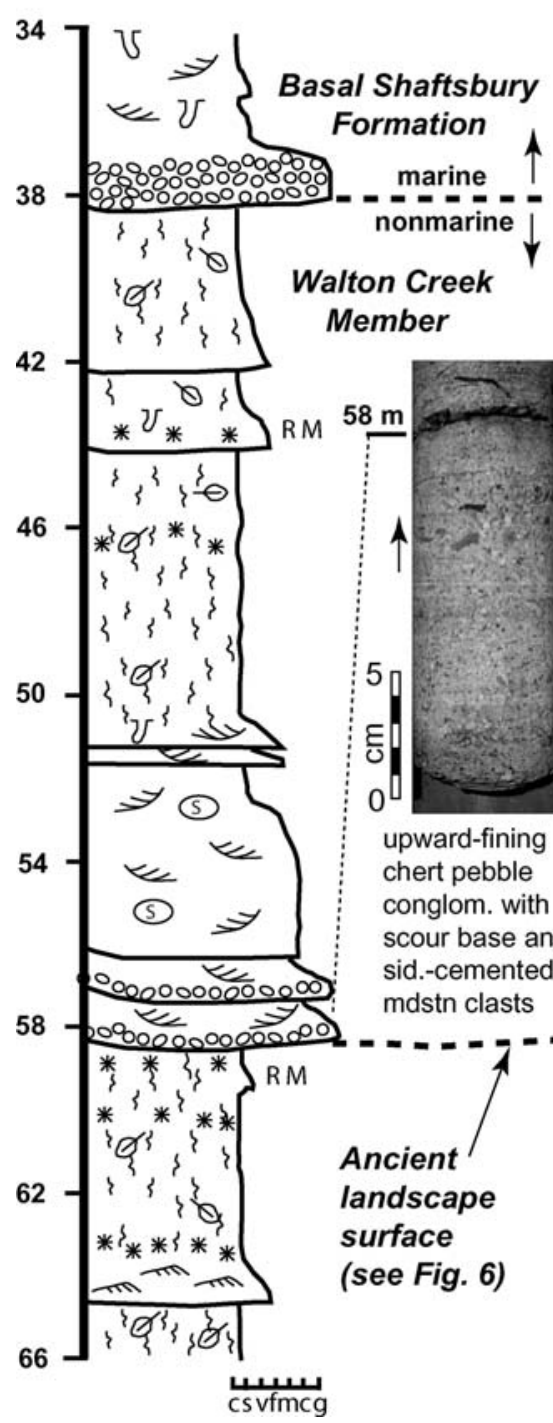

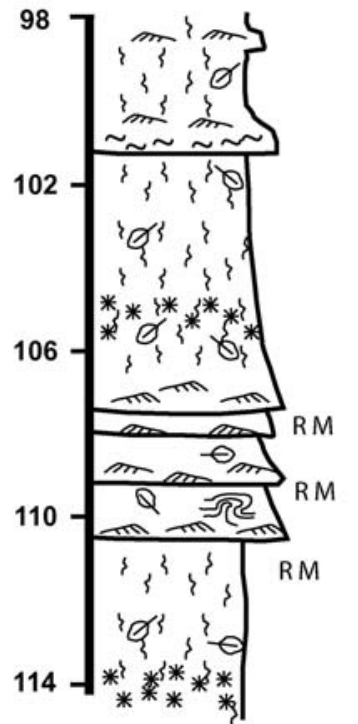

\begin{tabular}{|c|c|}
\hline$\{\xi\}$ & Paleosols \\
\hline ** & Sphaerosiderites \\
\hline$\varphi_{\sigma}$ & $\begin{array}{l}\text { Carbonaceous } \\
\text { debris }\end{array}$ \\
\hline$m$ & Small-scale ripple \\
\hline ש & $\begin{array}{l}\text { Large-scale trough } \\
\text { cross-stratification }\end{array}$ \\
\hline .88 & Chert-rich gravel \\
\hline$v$ & Burrows \\
\hline (5) & $\begin{array}{l}\text { Siderite-cemented } \\
\text { mudstone clasts }\end{array}$ \\
\hline RM & Red Mottling \\
\hline
\end{tabular}

FIG. 8.- Stratigraphic log of the Boulder Creek Formation MD 80-08 core, graphically illustrating the details of the lithofacies architecture. The chert-pebble conglomeratic sandstone that occurs between 52 and 58 meters depth in the core is interpreted to have been deposited during the aggradation phase which drowned the PM paleosols.
1998) obtained from the mean $\delta^{18} \mathrm{O}$ values of each sphaerosideritebearing horizon were used to estimate meteoric-water $\delta^{18} \mathrm{O}$ values for the Peace River area. The PM1-3 paleosols developed at approximately $52^{\circ}$ $\mathrm{N}$ paleolatitude according to the paleogeographic reconstructions of Scotese (1991). The groundwater $\delta^{18} \mathrm{O}$ values were modeled using the empirically determined zonal mean annual temperatures of Wolfe and Upchurch (1987) for $52^{\circ} \mathrm{N}$ paleolatitude, and the ${ }^{18} \mathrm{O}$ fractionation equation of Carothers et al. (1988). Barron (1983) estimated a range of paleotemperatures from $15^{\circ}$ to $25^{\circ} \mathrm{C}$ for $52^{\circ} \mathrm{N}$, and these values aid in predicting the potential variability in meteoric $\delta^{18} \mathrm{O}$ values. The groundwater $\delta^{18} \mathrm{O}$ values estimated from the isotopic values of the Paddy Member sphaerosiderites ranged between $-13.5 \%$ and $-12.0 \%$ (VSMOW) on the basis of the MAT estimates of Wolfe and Upchurch (1987). The meteoric-water values may have varied between $-14.2 \%$ and $-10.2 \%$ (VSMOW) on the basis of the paleotemperature range estimated by Barron (1983).

Minor Elements.-The sphaerosiderites analyzed from the $1754.35 \mathrm{~m}$ sample of PM 3 were greater than $95 \mathrm{~mol} \% \mathrm{FeCO}_{3}$, and show only minor enrichments in $\mathrm{Ca}, \mathrm{Mg}, \mathrm{Mn}$, and $\mathrm{Sr}$. Calcium substitutions ranged from $<1 \mathrm{~mol} \%$ up to $2.9 \mathrm{~mol} \%$, and $\mathrm{Mg}$ substitutions ranged from

TABLE 1.-Oxygen and carbon stable-isotope values of paleosol sphaerosiderite.

\begin{tabular}{|c|c|c|c|c|c|c|c|}
\hline Sample Interval & $\begin{array}{c}1653.2 \mathrm{~m} \\
(\mathrm{PM} \mathrm{1})\end{array}$ & $\begin{array}{c}1785.52 \mathrm{~m} \\
(\mathrm{PM} 2)\end{array}$ & $\begin{array}{c}1785.47 \mathrm{~m} \\
\text { (PM 2) }\end{array}$ & $\begin{array}{c}1785.21 \mathrm{~m} \\
\text { (PM 2) }\end{array}$ & $\begin{array}{c}\text { 1754.35m } \\
\text { (PM 3) }\end{array}$ & $\begin{array}{c}1754.05 \mathrm{~m} \\
\text { (PM 3) }\end{array}$ & $\begin{array}{c}1753.9 \mathrm{~m} \\
\text { (PM 3) }\end{array}$ \\
\hline Avg. $\delta^{18} \mathrm{O}$ VPDB, $\%$ & -10.36 & -9.58 & -9.07 & -10.27 & -8.96 & -9.54 & -9.34 \\
\hline$\delta^{18} \mathrm{O}$ std. dev., \%o & 0.33 & 0.53 & 0.41 & 0.26 & 0.30 & - & 0.45 \\
\hline Avg. $\delta^{13} \mathrm{C}$ VPDB, \% & 3.64 & -4.41 & -6.12 & -4.68 & -5.90 & -5.83 & -7.65 \\
\hline$\delta^{13} \mathrm{C}$ std. dev., \% & 0.37 & 0.43 & 0.91 & 0.96 & 0.76 & - & 0.36 \\
\hline No. of analyses $(\mathrm{N})$ & 10 & 8 & 8 & 10 & 19 & 1 & 8 \\
\hline
\end{tabular}




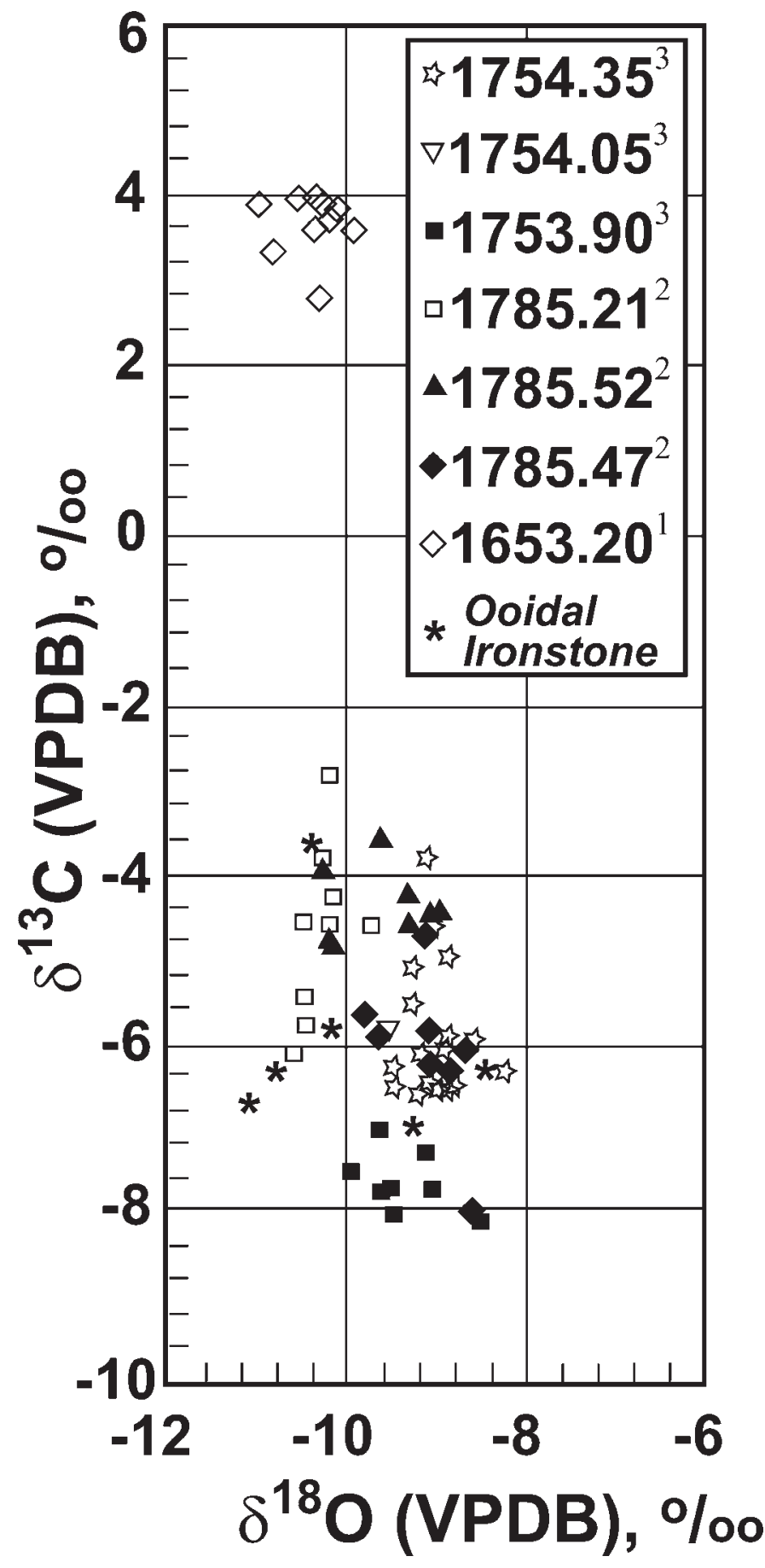

FIG. 9.-Carbon and oxygen isotope plot for all of the sphaerosiderites analyzed in the PM cores. The depth intervals or horizons are labeled with different symbols and the superscripts 1, 2, or 3 indicate the cores PM1, 2, or 3. The isotopic values reported by Taylor et al. (2002) from the ooidal ironstone unit of the Paddy Member are also included in the plot.

$<1 \mathrm{~mol} \%$ to $1.7 \mathrm{~mol} \%$. The $\mathrm{Mn}$ and $\mathrm{Sr}$ concentrations were all less than $1 \mathrm{~mol} \%$.

\section{Diagenesis}

The siderite nodules exhibit no evidence of dissolution, or replacement fabrics, and the textures and morphologies suggest that they were early diagenetic precipitates that developed during pedogenesis (Stoops 1983; Ludvigson et al. 1998). The $\delta^{18} \mathrm{O}$ values of the sphaerosiderites are depleted, generally exhibit low variance, and the $\delta^{18} \mathrm{O}$ vs. $\delta^{13} \mathrm{C}$ trends from a given horizon yield values consistent with a meteoric source (Lohmann 1988; Ludvigson et al. 1998). There is no evidence to suggest that the sphaerosiderites formed under high temperatures or from marine fluids, and the $\delta^{18} \mathrm{O}$ values are consistent with siderite $\delta^{18} \mathrm{O}$ values elsewhere in the area (Ufnar et al. 2001; Taylor et al. 2002). The groundwater $\delta^{18} \mathrm{O}$ values obtained from the sphaerosiderites are interpreted to reflect the isotopic values of local precipitation that recharged the surficial groundwater flow systems of the low-lying coastal wetlands (Ludvigson et al. 1998). The Paddy Member sphaerosiderites help constrain a Late Albian paleolatitudinal trend in meteoric $\delta^{18} \mathrm{O}$ values within the Western Interior Basin (White et al. 2001; Ufnar et al. 2002).

The $\delta^{13} \mathrm{C}$ values are variable, but they are generally within the range of organic-matter degradation (Pye et al. 1990). One exception is the $1653.2 \mathrm{~m}$ sample from PM 1. The $\delta^{13} \mathrm{C}$ values of this unit are all positive and likely indicate incorporation of ${ }^{13} \mathrm{C}$-rich dissolved inorganic carbon (DIC). Much of the bicarbonate present in the soil water may have been enriched in ${ }^{13} \mathrm{C}$ via $\mathrm{CO}_{2}$ reduction methanogenesis (Whiticar et al. 1986).

The pyrite present in the matrix and many of the sphaerosiderite nodules probably formed in situ (FitzPatrick 1984), and may indicate the production of $\mathrm{H}_{2} \mathrm{~S}$ by sulfate-reducing bacteria in the soil water. Iron and organic matter were abundant, thus the supply of sulfate in the soil water was likely the limiting factor on the formation of pyrite over siderite (Berner 1981). The occurrence of pyrite in the cores of the sphaerosiderite nodules suggests that there was an episode where an abundance of dissolved sulfate was introduced into the groundwater system. Pyrite began to precipitate with earlier-formed siderite acting as a favorable nucleation site, and then, after the available sulfate was consumed, conditions conducive to siderite precipitation ensued (Berner 1981; Pye et al. 1990). The presence of pyrite appears to be linked with late-stage hydromorphism in the paleosol, as discussed above. Marine fluids would be a likely source for dissolved sulfate, and perhaps marine fluids episodically infiltrated and mixed with meteoric phreatic fluids of the paleosols (Wright 1986). As the paleosols became very poorly drained, and passively drowned, marine fluids may have been introduced via storm surges or perhaps through tidal pumping (Ludvigson et al. 1996).

The ooidal ironstone that marks the boundary between the Paddy and Cadotte members contains early-diagenetic siderite cements with isotopic values that are very consistent with the isotopic values obtained from the PM sphaerosiderites (Fig. 3; Taylor et al. 2002). Taylor et al. (2002) suggested that the ooidal ironstones were deposited under estuarine conditions, and that the pore waters were likely fresh-water influenced.

\section{CONCLUSIONS}

(1) The reconstructed landscape between the Viking Formation, Paddy Member, and Walton Creek Member is a time line; but it is not an isochronous time line. These paleosols all began to form in different paleogeographic and paleoslope positions as sea level fell. The paleosol development changed at different rates and at different times as the seaway transgressed. Thus, the paleosols are genetically linked by the base-level (sea-level) changes, but each paleosol developed at different rates and times along the ancient landscape surface. This surface is significant because it is correlated into the marine realm, where chronostratigraphic relationships are better constrained, and it assists with age differentiation of sphaerosiderites which occur above or below this surface. The types of correlations produced here are critical for refining the time resolution of paleoclimatological reconstructions using the sphaerosiderite proxy. 
(2) The Paddy Member paleosols exhibit a polygenetic history of pedogenic development characterized by an earlier well-drained history of pedogenesis followed by late-stage hydromorphism. The changes in drainage conditions may be related to base-level changes associated with parasequence-scale relative sea-level changes that occurred during the early transgressive stages (transgressive systems tract) of the Kiowa-Skull Creek marine cycle.

(3) The soil development in each location is related to paleo-slope position (landward = Boulder Creek, basinward = Paddy Member; coastline $=$ upper Viking), and the passive drowning of the coast under conditions of rising sea level. Hydromorphism in the soils which developed in the upper Viking Formation correlated with deeply weathered, well-drained soils in the PM core area, and fluvial incision within the Boulder Creek. As base level rose, eventually the upper Viking area became fully marine, the PM soils began a hydromorphic phase of pedogenesis, and fluvial incision transitioned to valley filling and welldrained soil development on the interfluves in the Boulder Creek. With continued drowning, the PM area became estuarine, and the interfluve soils in the Boulder Creek became hydromorphic. Eventually the entire region was transgressed and covered by shales of the Shaftsbury Formation.

(4) The sphaerosiderite $\delta^{18} \mathrm{O}$ values of the Late Albian Paddy Member paleosols yield meteoric $\delta^{18} \mathrm{O}$ values that help constrain paleolatitudinal trends in meteoric isotopic values and contribute to our understanding of mid-Cretaceous greenhouse hydrologic processes. Data described in this paper have been archived and are available in digital format from the JSR data repository, http://www.sepm.org/archive/index.html.

\section{ACKNOWLEDGMENTS}

Support for this project was provided by National Science Foundation Grant \#EAR 96-28128, and graduate student research grants from the University of Iowa Center for Global and Regional Environmental Research and Sigma Xi. Special thanks are extended to Dr. Roger Walker for providing information and photographs of the paleosol described in Davies and Walker (1993). Thanks are extended to the Alberta Energy and Utilities Bureau Core Research Center in Calgary, and the University of Calgary for their hospitality. The authors greatly appreciate the thorough and thoughtful reviews of Dr. Tim White, Dr. Greg Retallack, and Dr. Jacqueline Huntoon. Thanks also to Dr. P. Lee Phillips for his assistance with core descriptions and sample collection.

\section{REFERENCES}

Alberta Study Group, 1954, Lower Cretaceous of the Peace River Region, in Clark, L.M., ed., Western Canada Sedimentary Basin, Ruthorford Memorial Volume: American Association of Petroleum Geologists, p. 268-278.

Barron, E.J., 1983, Warm equable Cretaceous, The nature of the problem: EarthScience Reviews, v. 19, p. 305-338.

BERNER, R.A., 1981, A new classification of sedimentary environments: Journal of Sedimentary Petrology, v. 51, p. 359-365.

Birkeland, P.W., 1999. Soils and Geomorphology, Third edition: New York, Oxford University Press, $430 \mathrm{p}$.

Bloch, J., Schroder-Adams, C., Leckie, D.A., McIntyre, D.J., Craig, J., and Staniland, M., 1993, Revised stratigraphy of the lower Colorado Group (Albian to Turonian), western Canada: Bulletin of Canadian Petroleum Geology, v. 41, p. 325-348.

Brewer, R., 1964. Fabric and Mineral Analysis of Soils: New York, John Wiley \& Sons, $470 \mathrm{p}$.

Bown, T.M., AND Kraus, M.J., 1993, Time stratigraphic reconstruction and integration of paleopedologic, sedimentologic and biotic events (Willwood Formation, Lower Eocene, northwest Wyoming, U.S.A.): Palaios, v. 8, p. 68-80.

Bullock, P., Fedoroff, N., Jongerius, A., Stoops, G., Tursina, T., and Babel, U., 1985, Handbook for Soil Thin Section Description: Wolverhampton, U.K., Waine Research Publications, $152 \mathrm{p}$.

Carothers, W.W., Lanford, H.A., and Rosenbauer, R.J., 1988, Experimental oxygen isotope fractionation between siderite-water and phosphoric acid liberated $\mathrm{CO}_{2}$ siderite: Geochimica et Cosmochimica Acta, v. 52, p. 2445-2450.

CECIL, C.B., 1990, Paleoclimate controls on stratigraphic repetition of chemical and siliclastic rocks: Geology, v. 18, p. 533-536.
Cecil, C.B., Stanton, R.W., Neuzil, S.G., Dulong, F.T., Ruppert, L.F., and Pierce, B.S., 1985, Paleoclimate controls on late Paleozoic sedimentation and peat formation in the central Appalachian Basin (U.S.A.): International Journal of Coal Geology, v. 5, p. 195-230.

Davies, S.D., and Walker, R.G., 1993, Reservoir geometry influenced by highfrequency forced regressions within an overall transgression: Caroline and Garrington fields, Viking Formation (Lower Cretaceous), Alberta: Bulletin of Canadian Petroleum Geology, v. 41, p. 407-421.

Dawson, G.M., 1881, Report on an exploration from Port Simpson on the Pacific Coast to Edmonton on the Saskatchewan: Geological Survey of Canada, Report of Progress 1879-80, Part B, p. 1-77.

FitzPatrick, E.A., 1984. Micromorphology of Soils: New York, Chapman \& Hall, 433 p.

Gibson, D.W., 1992, Stratigraphy and sedimentology of the Lower Cretaceous Hulcross and Boulder Creek Formations, Northeastern British Columbia: Geological Survey of Canada, Bulletin 440, $105 \mathrm{p}$.

Haq, B.U., Hardenbol, J., AND VaIL, P.R., 1987, Chronology of fluctuating sea levels since the Triassic: Science, v. 235, p. 1156-1167.

Kauffman, E.G., and Caldwell, W.G.E., 1993, The Western Interior Basin in space and time, in Caldwell, W.G.E. and Kauffman, E.G. eds., Evolution of the Western Interior Basin: Geological Association of Canada, Special Paper 39, p. 1-30.

Kraus, M.J., 1999, Paleosols in clastic sedimentary rocks: their geologic applications: Earth Science Reviews, v. 47, p. 41-70.

LECKIE, D.A., 1987, Late Albian sea level fluctuations: effects on the Viking and Boulder Creek Formations and the Paddy and Cadotte members: Canadian Society of Petroleum Geologists, Reservoir, v. 14, p. 1-2.

Leckie, D.A., And Reinson, G.E., 1993, Effects of Middle to Late Albian sea-level fluctuations in the Cretaceous Interior Seaway, western Canada, in Caldwell, W.G.E., and Kauffman, E.G., eds., Evolution of the Western Interior Basin: Geological Association of Canada, Special Paper 39, p. 151-176.

Leckie, D.A., And Singh, C., 1991, Estuarine deposits of the Albian Paddy Member (Peace River Formation) and lowermost Shaftsbury Formation, Alberta, Canada: Journal of Sedimentary Petrology, v. 61, p. 825-849.

LeCKIE, D.A., AND Smith, D.G., 1992, Regional setting, evolution, and depositional cycles of the western Canada Foreland Basin, in Macqueen, R.W., and Leckie, D.A. eds., Foreland Basins and Fold Belts: American Association of Petroleum Geologists, Memoir 55, p. 9-46.

Leckie, D.A., Fox, C., And Tarnocai, C., 1989, Multiple paleosols of the Late Albian Boulder Creek Formation, British Columbia, Canada: Sedimentology, v. 36, p. 307-323.

Leckie, D.A., Singh, C., Goodarzi, F., and Wall, J.H., 1990a, Organic-rich, radioactive marine shale: a case study of a shallow-water condensed section, Cretaceous Shaftsbury Formation, Alberta, Canada: Journal of Sedimentary Petrology, v. 60, p. 101-117.

Leckie, D.A., Staniland, M.R., and Hayes, B.J.R., 1990b, Regional maps of the Albian Peace River and lower Shaftsbury Formations on the Peace River Arch, northwestern Alberta and northeastern British Columbia: Bulletin of Canadian Petroleum Geology, v. 38A, p. 176-189.

Leckie, D.A., Schroder-Adams, C.J., Rosenthal, L., and Hall, J.H., 2000, An outcrop of the Albian Viking Formation and a southerly extension of the Hulcorss/ Harmon interval in west-central Alberta: Bulletin of Canadian Petroleum Geology, v. 48, p. $30-42$

Lohmann, K.C., 1988, Geochemical patterns of meteoric diagenetic systems and their application to studies of paleokarst, in James, N.P., and Choquette, P.W., eds., Paleokarst: Berlin, Springer Verlag, p. 58-80.

Ludvigson, G.A., Gonzalez, L.A., Witzke, B.J., Brenner, R.L., and Metzger, R.A., 1996, Diagenesis of iron minerals in the Dakota Formation, in Witzke, B.J., and Ludvigson, G.A., eds., Mid-Cretaceous Fluvial Deposits of the Eastern Margin, Western Interior Basin: Nishnabotna Member, Dakota Formation. A Field Guide to the Cretaceous of Guthrie County: Geological Society of America, North Central Section, Annual Meeting, Ames Iowa, Field Trip No. 1, Iowa Geological Survey, Guidebook Series, v. 17, p. 31-38.

Ludvigson, G.A., Gonzalez, L.A., Metzger, R.A., Witzke, B.J., Brenner, R.L., Murillo, A.P., And White, T.S., 1998, Meteoric sphaerosiderite lines and their use for paleohydrology and paleoclimatology: Geology, v. 26, p. 1039-1042.

MacEachern, J.A., Zaitlin, B.A., And Pemberton, S.G., 1999, A sharp-based sandstone of the Viking Formation, Joffre Field, Alberta, Canada: criteria for recognition of transgressively incised shoreface complexes: Journal of Sedimentary Research, v. 69, p. 876-892.

Mack, G.H., James, W.C., and Morger, H.C., 1993, Classification of Paleosols: Geological Society of America, Bulletin, v. 105, p. 129-136.

McCarthy, P.J., and Plint, A.G., 1998, Recognition of interfluve sequence boundaries: Integrating paleopedology and sequence stratigraphy: Geology, v. 26 p. $387-390$.

McCarthy, P.J., and Plint, A.G., 1999, Floodplain paleosols of the Cenomanian Dunvegan Formation, Alberta and British Columbia, Canada: Micromorphology, pedogenic processes, and paleoenvironmental implications, in Marriott, S.B., and Alexander, J., eds., Floodplains: Interdisciplinary Approaches: Geological Society of America, Special Paper 163, p. 289-310.

McCarthy, P.J., Martini, I.P., And Leckie, D.A., 1998, Use of micromorphology for paleoenvironmental interpretation of complex alluvial paleosols: an example from the Mill Creek Formation (Albian), southwestern Alberta, Canada: Palaeogeography, Palaeoclimatology, Palaeoecology, v. 143, p. 87-110. 
McCarthy, P.J., Martini, I.P., And Leckie, D.A., 1999a, Pedogenic and diagenetic influences on void coating formation in Lower Cretaceous paleosols of the Mill Creek Formation, southwestern Alberta, Canada: Geoderma, v. 87, p. 209-237.

McCarthy, P.J., Faccini, U., And Plint, A.G., 1999b, Evolution of an ancient coastal plain: paleosols, interfluves and alluvial architecture in a sequence stratigraphic framework, Cenomanian Dunvegan Formation, NE British Columbia, Canada: Sedimentology, v. 46, p. 861-892.

McConnell, R.G., 1893, Report on a portion of the District of Athabasca: Geological Survey of Canada, Annual Report, v. 5, part D.

Pattison, S.A.J., and Walker, R.G., 1992, Deposition and interpretation of long, narrow sandbodies underlain by a basinwide erosion surface: Cardium Formation, Western Interior Seaway, Alberta, Canada: Journal of Sedimentary Petrology, v. 62, p. 292-309.

Pattison, S.A.J., AND Walker, R.G., 1994, Incision and filling of a lowstand valley; the late Albian Viking Formation at Crystal, Alberta, Canada: Journal of Sedimentary Research, v. 64, p. 365-379.

Pattison, S.A.J., And Walker, R.G., 1998, Multiphase transgressive filling of an incised valley and shoreface complex, Viking Formation, Sundance-Edson area, Alberta: Bulletin of Canadian Petroleum Geology, v. 46, p. 89-105.

Pye, K., Dickson, J.A.D., Schiavon, N., Coleman, M.L., and Cox, M., 1990, Formation of siderite- $\mathrm{Mg}$-calcite-iron sulphide concretions in intertidal marsh and sandflat sediments, north Norfolk, England: Sedimentology, v. 37, p. 325-343.

Retallack, G.J., 1998, Fossil soils and completeness of the rock and fossil records, in Donovan, S.K., and Paul, C.R.C., eds., The Adequacy of the Fossil Record, New York, John Wiley \& Sons, p. 133-164.

SCOTESE, C.R., 1991, Jurassic and Cretaceous plate tectonic reconstructions: Palaeogeography, Palaeoclimatology, Palaeoecology, v. 87, p. 493-501.

SoIl Survey StafF, 1999, Soil Taxonomy A Basic System of Soil Classification for Making and Interpreting Soil Surveys: United States Department of Agriculture, Natural Resources Conservation Service, Agriculture Handbook no. $436,871 \mathrm{p}$.

STELCK, C.R., 1958, Stratigraphic position of the Viking Sand: Alberta Society of Petroleum Geologists, Journal, v. 8, p. 2-7.

Stelck, C.R., And LeCKIE, D.A., 1990a, Biostratigraphic constraints and depositional environment of the Lower Cretaceous (Albian) Boulder Creek Formation, Monkman area, northeastern British Columbia: Canadian Journal of Earth Sciences, v. 27, p. $452-458$.
Stelck, C.R., And Leckie, D.A., 1990b, Biostratigraphy of the Albian Paddy Member (Lower Cretaceous Peace River Formation), Goodfare, Alberta: Canadian Journal of Earth Sciences, v. 27, p. 1159-1169.

STOops, G., 1983, SEM and light microscopic observations of minerals in bog-ores of the Belgian Campine: Geoderma, v. 30, p. 179-186.

StotT, D.F., 1982, Lower Cretaceous Fort St. John Group and Upper Cretaceous Dunvegan Formation of the Foothills and plains of Alberta, British Columbia, District of Mackenzie and Yukon Territory: Geological Survey of Canada, Bulletin $328,124 \mathrm{p}$.

TaYlor, K.G., Simo, J.A., Yocam, D., and Leckie, D.A., 2002, Stratigraphic significance of ooidal ironstones from the Cretaceous Western Interior Seaway: The Peace River Formation, Alberta, Canada, and the Castlegate Sandstone, Utah, U.S.A.: Journal of Sedimentary Research, v. 72, p. 316-326.

Ufnar, D.F. Gonzalez, L.A. Ludvigson, G.A., Brenner, R.L and Witzke, B.J. 2001, Stratigraphic implications of meteoric sphaerosiderite $\delta^{18} \mathrm{O}$ compositions in paleosols of the Cretaceous (Albian) Boulder Creek Formation, NE British Columbia Foothills, Canada: Journal of Sedimentary Research, v. 71, p. 1017-1028.

UfNar, D.F GonzÁlez L A. Ludvigson, G.A., Brenner, R. L., and Witzke, B J 2002 The mid-Cretaceous water bearer: Isotope mass balance quantification of the Albian hydrologic cycle: Palaeogeography, Palaeoclimatology, Palaeoecology, v. 188, p. 51-71

WALKER, R.G., AND WISEMAN, T.R., 1995, Lowstand shorefaces, transgressive incised shorefaces, and forced regressions: examples from the Viking Formation, Joarcam area, Alberta: Journal of Sedimentary Research, v. 65, p. 132-141.

White, T.S., González, L.A., Ludvigson, G.A., And Poulsen, C., 2001, The midCretaceous greenhouse hydrologic cycle of North America: Geology, v. 29, p. 363-366

White, T., Witzke, B., Ludvigson, G., And Brenner, B., 2005, Distinguishing base-level change and climate signals in a Cretaceous alluvial sequence: Geology, v. 33, p. 13-16.

Whiticar, M.J., Faber, E., and Schoell, M., 1986, Biogenic methane formation in marine and freshwater environments: $\mathrm{CO}_{2}$ reduction vs. acetate fermentationisotopic evidence: Geochimica et Cosmochimica Acta, v. 50, p. 693-709.

Wolfe, J.A., AND UPChURCH, G.R., JR., 1987, North American nonmarine climates and vegetation during the Late Cretaceous: Palaeogeography, Palaeoclimatology, Palaeoecology, v. 61, p. 33-77.

Wright, V.P., 1986, Pyrite formation and the drowning of a palaeosol: Geological Journal, v. 21, p. 139-149.

Received 5 May 2004; accepted 10 March 2005. 